\title{
Caliphates and Juntas: Ottoman Legacies in Today's Controversies over Religion and State in the Arab World
}

\author{
Juan Cole
}

Egypt and Iraq display contrasting policies in the relationship between state and religion. Egypt's nationalist officer corps has subordinated political Islam, stigmatized the Muslim Brotherhood, and bended clerics to its will. While Arab Iraq presents two models, both hold a similar stance on religion: one an elected, parliamentary government dominated by political Islam and Shiite clerics; the other a theocratic Sunni caliphate of the Islamic State of Iraq and the Levant. Egypt and Iraq are heirs to two differing Ottoman solutions to the problem of religion-state relations, the legacy of which is often overlooked. The most prevalent model subordinates clergy and religion to the state in the tradition of Mehmet I. This model is characteristic of the empire in its glory years and would have been recognized by Suleyman the Magnificent. In the other model, the late-nineteenth-and early-twentieth-century Hamidian caliphate, the head of state claimed temporal and religious authority to combat colonial penetration. Neither Ottoman nor colonial norms of governance, nor nationalist states succeeding them, developed methods to deal with multiethnic states or avoid a tyranny of the majority. Unlike the modernizing Ottoman caliphate, however, the caliphates of Mulla Omar and Ibrahim al-Samarra'i display a literalist reading of sharia and a ruthless disregard of humane prohibitions in mainstream Islamic law against killing innocents. Of the two models, the likely victor is the state-centric subordination of religion because latter-day caliphates have flourished only briefly as radical and sectarian movements in rugged territories where power vacuums existed.

Nearly two decades into the twenty-first century, Egypt and Iraq stand out as nearopposites with regard to the relationship between state and religion. Egypt's nationalist officer corps, in power save for a single year 1952 through the present, has cracked down hard on political Islam, stigmatizing the Muslim Brotherhood as a terrorist organization. It has also carefully subordinated the Muslim clerical corps, led by the al-Azhar seminary, to its political will. In contrast, Arab Iraq in 2014-17 fell into two zones: one an elected, parliamentary government dominated by political Islam of the Shiite persuasion wherein clerics were independent and influential, and the other a theocratic Sunni caliphate of the so-called Islamic State of Iraq (ISI) and the Islamic State of Syria and the Levant (ISIL). To contrast nationalist, praetorian Egypt with Islamist Iraq obscures many commonalities because most Muslim Egyptians report themselves in polls to favor implementation of Islamic law, and Sunni Arab Iraqis in particular have a strong secularist bent, regardless of the religious militias that briefly took over their lives. Still, these very different forms of governance being experimented with in a way replicate state-religion policies of the late Ottoman Empire, the legacy of which is too often discounted in the contemporary Arab world. 
Egypt was ruled directly from Istanbul from 1517 to 1882 and continued to be considered a British protectorate of an Ottoman province until 1914. Iraq was ruled by the Ottomans, directly or indirectly, from 1534 until the British conquest during World War I.

The Ottoman ruler was for the most part viewed as a temporal sultan, not as a religious figure. The religious establishment, headed by the Şeyhülislam, was firmly subordinated to the state. Courtiers sometimes flattered the sultans as having the status of caliph (the Muslim equivalent of a pope), but there was no institutional reality behind such compliments. By contrast, the brief experiment with attempting to claim more than a pro forma caliphate on the part of the last Ottoman sultans from 1880 set another dynamic in motion. When that caliphate crashed and burned in the detritus of World War I, it created a myth that the subsequent weakness and subordination of the Muslims was a consequence of the absent caliph. Late-twentieth- and early-twentyfirst-century movements such as Hizb ut-Tahrir, al-Qaeda, the Taliban, and the ISIL aspired to the restoration of the idea of the commander of the faithful as a center of both religious and secular authority. That is, both the nationalist state of President Abdel Fattah al-Sisi in Egypt and the rump caliphate of Abu Bakr al-Baghdadi in northern Iraq and eastern Syria in 2014-17 reflect differing Ottoman religious policies, though al-Sisi is closer to the norm of the Ottoman state. The Ottoman legacy is apparent in two other related phenomena. The Sunni Ottoman elites at the top of the empire never found a way satisfactorily to incorporate its Shiite Muslim subjects, and the claim on the caliphate and Sunni bases for rule exacerbated this divide in the late nineteenth and early twentieth centuries. Finally, its inability to accommodate itself to popular demands for democracy and a rule of law (1876-77 and 1909-12) left behind a thoroughly authoritarian political tradition.

The supremacy of the temporal Ottoman sultans over religious affairs was underlined by their claim on the right to legislate, apparently influenced in this regard by the Mongol tradition. Genghis Khan was alleged to have issued a law code, the Yasa, which after the Mongol conquest of Iran coexisted with and often overruled the Muslim sharia. The Ottomans continued this tradition of legislating criminal, commercial, and administrative law, which is different from the medieval Mamluk notion of public policy (al-siyasah al-shar'iyyah) or the issuance of regulations by the ruler to fill out gaps where Islamic law or sharia is not explicit. The statutes issued by the sultan were known as canons (qanun), and they often departed from the sharia or the Muslim legal code as adumbrated by medieval jurists (Fleischer 1983: 198-220). Sultan Süleyman's edicts on criminal law for instance, which included burning at the stake for arson and exile for theft (neither of them quranic), were intended to express the interests of the state and perhaps to place the sultan above the ulama or Muslim clerics. One scholar of the empire wrote,

Mehmed the conqueror established seyhulislamlik, to control the activities of local muftis, ve'izs [wa'izs], imams of the mosques, and mutevellis [mutawalis] of vekifs [waqfi]. During the reign of Suleyman (1520?-1566) or a little later, the seyhulislam [Shaykh al-Islam] received more power and responsibility. $\mathrm{He}$ 
was given full authority to appoint kazaskers and kadis [judges] who had a salary above 40 akces daily. Many Ottomanists believe that this development was caused by the popularity and influence of the incumbent şeyhülislam Ebussud Celebi (d. 1574). In my opinion, in addition to that, the dualistic nature of the ilmiye [clerical] leadership (şeyhülislamlik and kazaskerlik) did not work effectively to create monolithic support for the court programmes and interests. Through such a system it was possible for the sultan to easily check religious protest of one segment with the help of the other (Mansurnoor 1992: 35-51).

Not only did the Ottoman emperors lack any institutional appurtenances of a caliphate, it seems likely that most of their subjects discounted the occasional attempt to attribute to them a religious charisma. In the eighteenth century, Ahmad al-Damanhuri, a rector of al-Azhar Seminary in Cairo, the foremost center of Sunni learning, wrote an essay in which he was frank that the caliphate ended in 1258 and that the Ottomans were kings, not caliphs. The Sunni caliphate had lapsed. He said, however, that some of the Ottomans were better and more just rulers, as temporal monarchs, than some of the Umayyad and Abbasid caliphs had been (Al-Damanhuri 1767-78: 10). I know of no reason to think that al-Damanhuri's views weren't the prevailing ones on the eve of Middle Eastern modernity.

The nineteenth-century modernizing reforms (Tanzimat) of the Ottomans and their vassals in the metropole and in Egypt were not explicitly anticlerical, and indeed the reforms were framed as having clerical support and being in accord with Islamic law. But in practice they often did create tensions between the clerics or ulama and the temporal state. In the provinces, some notable families had come to view religious office as a hereditary right, but from the 1860s the appointments to offices such as court judge (qadi) and leader (naqib) of the caste of descendants of the Prophet had to be confirmed from Istanbul (Yazbak 1997: 71-91). The 1856 Treaty of Paris, ending the Crimean War, pledged the Ottoman state to treat its Christian and Muslim subjects equally under the law, a principle rejected by the ulama who held to their sharia tradition, which gave Muslims privileges over non-Muslims (Davison 1963).

In Egypt, Viceroy Mehmet Ali Pasha's introduction of Western-style uniforms into the army outraged some ulama and inspired in them fears of mass apostasy (because of the saying attributed to the Prophet Muhammad that whoever imitates a people becomes one of them) (Fahmy 1997). Mehmet Ali in any case much reduced the power of the ulama. In the late eighteenth century, some one-fifth of land was held in the form of waqf or pious endowment, often to support religious or charitable institutions, and the ulama often served as endowment overseers, receiving a percentage of the annual income generated by endowed lands. Mehmet Ali taxed, and then resumed, much of the waqf land for state purposes, leaving the clerics with fewer sources of income and less independence from the state because state salaries were now their main emoluments (Sayyid-Marsot 1984: 67-69). In some ways this KhedivialOttoman reform predicted the difference between the Egyptian ulama, who have mostly supported the state and the Shiite clergy of Iran and Iraq, who have been more independent of it in modern history. 
During the reign of Said Pasha, in the 1850s to early 1860s, one chronicler mentioned severe tension in the officer corps between the more secular-minded officers and the more religious ones. The Khedive was said to have despised any officers who said their five daily prayers while in uniform (Cole 1993: 28; Taymur 1967: 64-65). In part under French influence, he saw the military as an apparatus of the civil state. The unease of the modern professional military in the Middle East with religious authority is, then, a dynamic that goes back to the Ottoman era. The role of the officer corps in overthrowing Muslim Brotherhood leader Muhammad Morsi in 2013 is a contemporary manifestation of this tension.

Another heritage of Ottoman practice was the privileging of Sunni Islam over the Shiite branch and the promotion of Sunni mission among Shiites. In early modern Ottoman Iraq, Shiites were coded as a pro-Iranian fifth column and actively persecuted. Once the empire was on surer footing, it absorbed large Shiite populations (both Twelver and heterodox) in Lebanon, Syria, Yemen, and Anatolia, and watched helplessly through the nineteenth century as southern Iraq largely adopted Shiism. Powerful Shiite clans served in the Ottoman military, and Lebanese Shiites acquitted themselves well in the conquest of Yemen. The Ottomans steadfastly declined to recognize Shiites as a corporate group (as they did Christians and Jews), insisting that they be categorized as ordinary Muslims. In the era of the Tanzimat reforms of the nineteenth century, the idea of Osmanlilik or common Ottoman citizenship, was promulgated. Still, in the 1890s there were state-supported missions to the Alawis in Syria and the Twelver Shiites in Iraq, which hoped to convert them to the majority tradition. In the early twentieth century there was even a blasphemy trial in Ottoman courts of Syrian Ismaili Shiites (Cole 2002a: ch. 1). Shiites did not for the most part recognize a Sunni caliphate, but could accommodate a common-law sultanate.

Sultan Abdulhamid II, like other sultans, inherited the flowery, unsubstantive claims to be caliph on coming to power in 1876 . These were not accepted by many Muslims, in part because of a conviction that only members of the Prophet Muhammad's clan, the Quraysh, could assume that office, or because, as with Khedive Ismail Pasha of Egypt, other rulers coveted the status (Buzpinar 1996: 59-89). According to the Iranian diplomat in Istanbul Malkom Khan, in 1880, Sultan Abdulhamid II decided to make a more robust and practical claim on the caliphate than had any of his predecessors (Khan 1970). In large part this ploy derived from Istanbul's annoyance at the ways in which the European powers were deploying a religious policy against the Ottomans. The Russians were claiming the role of protector of the Eastern Orthodox Christians under the rule of the sultan. The French, despite their turn to secularism from 1870, were nevertheless posing as protectors of the Maronites of Mt. Lebanon, the Chaldeans of Mosul, and the small number of Catholics in the region. Even the British had adopted the esoteric sect of the Druze as objects of compassion. Abdulhamid II considered turnabout fair play, and intended his caliphal pretensions as a platform on the basis of which he could interfere in French Algeria, Russian Turkestan, and British India. He also reached out even to the Shiites of Iran and Iraq, who, despite their doctrinal aversion to any claim of a caliphate, might be convinced of the need for Sunni-Shiite political unity in the face of the European colonial onslaught (Cole 2002b: 167-85). 
It is difficult to know how well accepted Abdulhamid II's claim to the caliphate became over time. A British investigation after the Urabi Revolt of 1881-82 was put down said it found little evidence that Egyptians even knew about the sultan's claim to the caliphate (Stuart 1883, 1: 103). Things were different in British India. The claim became the basis for the Khilafat movement in British India during and just after World War I, the leaders of which were disturbed by their own government being at war with the Ottoman sultan-caliph. After the war, they feared that the British would connive at the abolition of the caliphate (Minault 1982). Similar public movements for the Ottoman caliphate are not known in other regions of the Muslim world, which suggests that Muslims elsewhere were not very invested in this notion.

The European attempt to occupy and carve up the Turkish-speaking provinces of the Ottoman Empire after World War I was thwarted by ex-Ottoman officers and a growing nationalist movement led by Mustafa Kemal Ataturk. The Turkish nationalist guerrillas undid the humiliating Treaty of Sevres (1920) and gained instead the much more favorable terms of the Treaty of Lausanne (1923). The Turkish parliament declared a republic in 1923, deposing the last sultan. The following year the national legislature abolished the caliphate, moving the country toward being a secular republic on the model of the French Third Republic. Indeed, advocating for a caliphate thereafter was made punishable in Turkish law (Liebl 2009: 373-91).

The 1924 Turkish parliamentary decree that there was no caliph, undoing Sultan Abdulhamid II's policy of 1880 and after, set off a lively if little-studied debate in Cairo and elsewhere in the Middle East and South Asia. Some Egyptian clerics authored manuscripts in the mid-1920s insisting on the necessity of a caliphate. Famously, Ali Abd al-Raziq, an Egyptian secular court judge, authored a major book arguing that Islam could be practiced by individual believers without the necessity of a caliph (Ali 2009). Abd al-Raziq's position became the commonsense one for the Arab republics.

The scramble in the 1920s to see if any contemporary Muslim leader might replace the abolished Turkish caliphate (which was more an affectation of the last sultans than a distinct religious office) ended fruitlessly. Sharif Husayn in Mecca put forward a claim in 1924, drawing a sharp reaction from the Saudi monarchy in Najd, which annexed the Hejaz and deposed Husayn later that year, depriving him of any platform for pursuing the matter (Teitelbaum 2000: 412-24). King Fuad in Egypt also toyed with the idea. A "Caliphate Congress" was held at al-Azhar University in Cairo in 1926 in a search to fill the gap its participants saw as having been opened up by the decree of the Turkish parliament. The attendees, however, could not come to an agreement. None of the temporal powers in the Muslim world at that time wanted to see a rival add to his secular authority the religious charisma of the office of the caliphate, and in the end no claim was successful (Kazimi 2008: 12-13).

Sunni Islam in the Arab world in some significant ways thereafter went the way of Christian Protestantism, which is for the most part organized on a national basis. Thus, there is a Swedish Lutheran Church and a German Lutheran Church. Likewise, each Sunni country has a mufti or jurisconsult, appointed by the head of state. Sunni ulama or clergymen lack much state authority, being largely subordinated to temporal authorities, and their relationship to the laity is that of pastors. Unlike the maraji ${ }^{\circ}$, or 
sources for emulation of the Shiite clergy, there is no mandate that laypersons blindly obey or emulate (taqlid) their rulings.

The issue seemed to have been left in the dust by the post-World War II processes of decolonization, which saw many Muslim countries fall under secular rule. The Egyptian Young Officers of 1952, 'Abd al-Karim Qasim, and later the Baath Party in Iraq, the Baath in Syria, the Bourguibists in Tunisia, the National Liberation Front (FLN) in Algeria, and the Kemalists in Turkey all based themselves on a secular ideology, which they often imposed on the nation-states they were creating with secret police and the army. The conservative monarchies that formed the other pole of Arab politics were as little interested in a revived caliphate as were the Marxisant Arab nationalists, insofar as it would have created a rival to their own religious charisma as Muslim monarchs.

There was relatively little conflict between the al-Azhar Seminary (which is also now a modern university) and the military nationalist state in Egypt in the 1950s through the 1970s. This relative harmony derived from the replication in republican Egypt of the old Ottoman and khedivial model of temporal dominance of the religious institution. Gamal Abdel Nasser put the clergy under strict constraints and insisted that al-Azhar be reformed so as to offer a modern, scientific education. Both in the Sadat era of the 1980s and again from 2013 there was a push to disallow private mosques and to ensure that clergy were on the state payroll and their sermons under the eye of state censors. In the 1990s, al-Azhar gained some influence on Egyptian government policy and legislation, but only because the state saw its moderate clerics as key allies in combatting the rise of radical movements as well as the increasingly popular, populist Muslim Brotherhood (Zeghal 1999: 371-99). In countries like Tunisia, Syria, and Iraq during the 1970 s and after, there was no question of the clergy or religious groups challenging the state, and those who did were crushed (Pierret 2013).

In contrast, there has been substantial conflict between the Egyptian state and the Muslim Brotherhood (Wickham 2013). Founded in 1928 in the aftermath of the abolition of the Hamidian caliphate, this organization sought to restore religion to the center of politics, yearning for a "Supreme Guide." Whether al-Banna wanted a neocaliphate is controversial, but he clearly wanted politics infused with religious authority. Because the nationalist republic in Egypt after 1952 subordinated religious institutions to temporal purposes, while nevertheless making compromises with them, it was bound to come into conflict with a theocratic organization. Insofar as it is populist and rejects state control, it does not fit either Ottoman model of religionstate relations. It is not on the state payroll or subordinate to the "sultan." But neither has it been able successfully to combine state and religious power in a "caliphate," as Abdulhamid II tried to do.

The Brotherhood's one year in power in Egypt was as a constitutional party with a republican president, not as a caliphate, and even the former role proved threatening to Egypt's nationalist establishment and public. During the years 2012-13 when the Brotherhood had the presidency and crafted a constitution, they attempted to give the al-Azhar Seminary and its clergy more power by making them responsible (rather than the supreme court) for interpreting those parts of Egyptian law rooted in the 
sharia (Cole 2014: ch. 6). This move violated the Ottoman principle that ultimately the state decides on what the law is, and the temporal ruler cannot be overruled by the ulama. That paragraph was removed from the 2014 constitution crafted at behest of the generals, who made a coup against the Brotherhood government.

I would argue that it is the Hamidian caliphate, not the medieval one, that is the practical referent of attempts to revive the institution by radical fundamentalists in the late twentieth and early twenty-first century - though it is natural that they should also reference the orthodox caliphs who followed Muhammad. In a video interview issued in 2001 after the September 11 attacks, Usama Bin Laden said that al-Qaeda had caused the West to taste some of what had befallen the Muslim world for the previous 80 years. His admittedly obscure referent was likely the 1924 abolition of the caliphate, though some have argued that it was the colonial mandates established after World War I. Because, however, the Mandate era and the abolition of the caliphate went hand in hand and both resulted in a division of the previous Ottoman Empire into a congeries of relatively small polities subordinate to the West, it would be difficult to disentangle these processes. After the US invasion of Iraq, Bin Laden urged that a neocaliphate be established in Baghdad, though it was never his top priority (Pankhurst 2010: 530-52). He adopted from the radical Hizb ut-Tahrir, founded in 1952 in Jordan but now active in 40 countries, the diction that each modern Muslim nation-state is only a province (wilayah), that is of the caliphate, which should be cleansed of non-Muslims (Ahmed and Stuart 2010: 143-209; Karagiannis 2006: 261-80). Mulla Omar of the Taliban at one point went to a shrine near Qandahar and put on a relic, the alleged cloak of the Prophet Muhammad, in an apparent symbolic claim on the caliphate for himself. He was styled by the Taliban the "Commander of the Faithful" or Amir al-Mu'minin, an epithet applied to the caliphs (Cole 2003: 771-808; cf. McCants 2015: 143-44).

A caliphate was declared in 2014 by Dr. Ibrahim al-Samarra'i, under the nom de guerre of Abu Bakr al-Baghdadi (McCants 2015; Terrill 2014: 13-23). Like the Taliban in its heyday, al-Samarra'i gained territory before declaring his caliphate. By the summer of 2014, the area from al-Raqqah in Syria to Tikrit in Iraq constituted the core of his statelet. These are areas that had been ruled by Abdulhamid II, but then fell into Christian British, and later, secular Baathist or Shiite hands. Given the collapse of the Arab nationalist model for Sunni Arabs alienated from the Baath Party in Syria and Iraq, some Sunni leaders attempted to revive the previous form of indigenous government, the Hamidian caliphate of the period before 1924. In part, they framed this endeavor as an anticolonial movement, though it had been indigenous forces in the old Ottoman Empire, that is the officer corps based in Anatolia, which had decided to abolish the caliphate. Al-Samarra'i, though he likely was not conscious of the precedent, pushed forward the late Ottoman discrimination against and insistence on conversion of Shiites. Admittedly, the late-nineteenth-century Ottoman efforts, with regard to Shiites and the heterodox, were far gentler than the virtually genocidal policies of al-Samarra'i.

The fall of Mosul in June 2014 came at the end of a long series of disappointments for Iraq's Sunni Arab population. This community, perhaps 17 percent of the country's 33 million population, had been disproportionately present in the upper echelons of 
the Arab nationalist, socialist, and authoritarian one-party state of the Baath Party, 1968-2003. And, of course, Iraq inherited a tradition of Sunni elite rule from the Ottoman Empire. The excesses of the Baath Party made it anathema to many Iraqis, especially to Shiite and Kurdish activists, but also Sunni Salafis. Still, it should be remembered that half of middle- and lower-ranking Baath officials had been Shiites from the south.

After the Bush invasion and occupation, the US government and its Kurdish and Shiite allies created a new power reality in the form of a government they dominated through their large populations and parliamentary elections (Cole 2009: ch. 4; Dodge 2013). They established a "Debaathification Commission" in 2003 that engaged in lustration practices, that is marked Sunnis as unsuitable for public office for their Baath links. While US officials argued that only high officials should be excluded from government positions, the commission fired people down to the level of schoolteacher, tossing tens of thousands of Sunni Arabs out of government jobs in 2003-4 when the private sector shrank to almost nothing. At the same time, the neoliberal US officials allowed state economic enterprises and factories to evaporate. The result was a massive wave of unemployment in the Sunni Arab provinces and rapid downward mobility for their once-prosperous middle and upper-middle classes. In essence, the Bush administration installation of the Shiites in control in Iraq was a reversal of the late Ottoman heritage in that country's social structure, which had privileged a Sunni elite even as the southern tribes converted after 1750 overwhelmingly to Shiism.

Guerrilla resistance movements to the new order grew up through 2003 and 2004 in the Sunni Arab regions. Most were based on neighborhood, tribe, or other social circles. Most Sunni Arabs remained secular in outlook, having been brought up Baathists, and believing in a separation of religion and state. But a determined minority gravitated toward Abu Musaab al-Zarqawi's al-Qaeda in Mesopotamia, established after the US invasion. Al-Zarqawi, a Jordanian who had been in Afghanistan in the late 1980s and early 1990s, sought to unite the Muslim fundamentalist guerrilla groups under his leadership, and offered his bay 'ah or pledge of fealty to Usamah bin Laden of al-Qaeda. It is likely that he began thinking of establishing a caliphate in Iraq.

The American conviction that Falluja was a center for Salafi radicalism led to the November 2004 destruction of that city by the US military. Sympathy protests broke out in most Sunni Arab-majority cities in the aftermath, and Sunnis announced that they would not participate in the elections scheduled for January 2005. Those elections were conducted on a national, proportional system implemented by the United Nations, with the result that groups that boycotted them received zero representation (in contrast to a district-based system where constituencies would return a representative even in conditions of low turnout).

Shiite leader Grand Ayatollah Ali Sistani had insisted that the Iraqi constitution not be written by the American viceroy Paul Bremer, but be crafted and voted on by an elected constituent assembly and then subjected to a national referendum. The constituent assembly elected in late January 2005, however, had almost no Sunni Arabs because of the boycott, so the assembly drafted a constitution that suited Kurds and Shiites, with extensive decentralization and other measures rejected by 
the then-nationalist Sunni Arabs. In the October 2005 referendum, all three SunniArab-majority provinces roundly rejected this constitution, which can be seen as the beginning of their 2014 secession.

The electoral system used in Iraq, a list system, foregrounded party over candidates. As electoral politics developed, parties tended to be ethno-sectarian rather than nationwide or thematically based. The Sunni Arabs have wildly fluctuated in their political experiments (showing the most voter volatility in the electorate), supporting the Iraqi equivalent of the Muslim Brotherhood in December 2005, but then swinging to the secular Iraqiya Party in 2010 (Cole 2011: 49-71).

The originally united Shiite bloc, representing 60 percent of the country, has split into two major coalitions. One, led by the fundamentalist lay Da'wa (Islamic Call) Party, grouped smaller parties in the State of Law Coalition. The other is an alliance of the clerically led Islamic Supreme Council of Iraq (ISCI) and the puritanical and populist al-Ahrar or The Party of the Free, guided by cleric Muqtada al-Sadr. The Shiite electorate, unlike the Sunni Arabs in 2010, for the most part declines to vote for a secular party. In the two elections of 2005, first for a constituent assembly and then for a permanent four-year parliament, the Shiite parties, united at the instance of Grand Ayatollah Sistani into the United Iraqi Alliance (UIA) coalition, easily won a majority and were able to form a government. In part to mollify Sunni Arabs and Kurds and the Arab League and the United States, the UIA developed a custom of selecting a lay leader of the $\mathrm{Da}^{\text {' } w a ~ P a r t y ~ a s ~ p r i m e ~ m i n i s t e r ~ r a t h e r ~ t h a n ~ a ~ c l e r i c ~ f r o m ~}$ ISCI or the Sadr Bloc. Over time Da'wa leaders (Ibrahim Ja'fari, Nouri al-Maliki, and Haydar al-Abadi) turned the advantages of incumbency into a standing mandate for Da' wa to hold the prime ministership.

Because Iraq so far has only one chamber of parliament, and because Sunni Arabs comprise some 17 percent of the population-and because politics is pursued on the basis of ethno-sectarian parties - the Sunni Arabs are doomed to lose every vote for the foreseeable future. The two Shiite blocs can usually ally with one another, but almost never with the Sunni Arab bloc. Shiite cross-ethnic alliances instead tend to be with the Kurdish parties. Sunni Arab hopes in parliamentary-led reform have therefore been repeated dashed.

Former members of the Baath officer corps from the Sunni Arab community along with a fringe of Salafi hardline fundamentalists who had come under Saudi influence formed some 60 major guerrilla groups to fight the US occupation and the new government it was fostering. In February 2006 it is likely al-Qaeda in Mesopotamia that demolished the Golden Dome shrine of the eleventh Shiite Imam in Samarra just north of Baghdad. This attack on so potent a religious symbol set off a Sunni-Shiite civil war in 2006-7 that led to the ethnic cleansing of a majority of Baghdad Sunni Arabs.

The ethno-religious clashes were made even more bitter by the soft-target brand of terrorism practiced by al-Qaeda in Mesopotamia, which in 2007 became the ISI. They targeted civilian noncombatant Shiites for destruction by suicide belt bombs and car bombs, including crowds of children at an ice cream shop or celebrants gathered at a wedding. Chasing Sunni Arabs from mixed neighborhoods was the response of 
the Shiite militias, removing populations within which the guerrillas were hiding out. Baghdad, an object of pride for its centuries of cultural and religious significance to Muslims, became an overwhelmingly Shiite city. There is some evidence that the Shiite militias who pursued this ethnic cleansing strategy were advised by the Iranian Revolutionary Guards Corps.

Prime Minister Nouri al-Maliki of the Da'wa Party came to power in 2006 and managed to continue in power until the secession of the Sunni Arab provinces in 2014 created a crisis that forced him out, in part at American insistence. Al-Maliki had been the Da'wa bureau chief in Damascus in the 1980s and 1990s, conspiring to overthrow Saddam Hussein, and had a conspiratorial mind-set and a profound distrust of Sunnis. Al-Maliki's Shiite majority in parliament declined to allow US troops to remain in Iraq in 2011. Whereas initially the United States had attempted to form a new Iraqi army on a nonsectarian basis, al-Maliki inducted former members of Shiite militias into the military and the Interior Ministry gendarmerie in large numbers, so that over time the national security forces came to be heavily Shiite.

The al-Maliki government tended to exclude Sunni Arabs from any real say, and it was inaccurately called "Safavid" by Sunni Arab fundamentalists, referring to the few decades (1624-38) of Iranian Shiite rule of Iraq under Shah Abbas of the Safavid dynasty, which ended when Ottoman sultan Murad IV reconquered it (Aljazeera 2015). The Da 'wa Party tends to be made up of lay Shiites who rejected the Khomeinist doctrine of clerical rule, and the Iraqi government had prominent Sunni politicians in it, even if they seldom had a great deal of power. Still, the vacuum of power created by the American overthrow of the Iraqi government allowed politicians and militia leaders to mobilize Iraqis on the basis of a Sunni-Shiite division more powerfully than at any time since the contest between Ottoman Sultan Murad IV and Safavid Shah Abbas.

In the 2010 parliamentary elections, the secular Iraqiya Party, backed by the Sunni Arabs in that election, won 91 seats in parliament, making it the largest single party. The Shiite party of the religious right, the Da'wa, gained 89 seats, and the clerical Shiite bloc won 41 . The Iraqi constitution appears to require the president to ask the party with the largest number of seats to form the government, which would have been Ayad Allawi, a secular Shiite ex-Baathist, of Iraqiya. But with the intervention of the Iranian Revolutionary Guards, the Da'wa and its Shiite clerical rivals managed to form a postelection coalition that gave them 120 seats, and with tacit Kurdish support, a majority. The Iraqi Supreme Court ruled that postelection coalitions could be formed and should be taken into account by the president in asking party leaders to form the government. And so al-Maliki was again prime minister. The Sunni Arabs who had voted for Iraqiya ( 80 percent of its support base) felt cheated and felt hopeless about their political future. The Shiite coalition won again in the elections of spring 2014.

In 2011, with the outbreak of the youth revolts in Egypt, Tunisia, and elsewhere, Sunni Arab youth in northern and western Iraqi cities also protested (Al-Rawi 2014: 916-42). They alleged that Baghdad was declining to share the country's oil bonanza equitably with Sunni Arab areas, which were suffering from lack of government services, electricity, and employment for young people. The al-Maliki government 
dealt harshly with these protests in 2011-13, at some of which admittedly, the ISI took advantage of the social turmoil to snipe at Iraqi troops. In some instances, helicopter gunships were deployed against civilian crowds. In the period 2011-15 some Sunni Arab towns and villages were in constant rebellion against Baghdad, some hosting ISI fighters, and were under regular artillery barrages by the Iraqi army.

In 2011, as well, the Syrian revolution gradually turned into a civil war, as the Baath government of Bashar al-Assad deployed tanks and artillery against initially peaceful crowds. The so-called ISI group saw another fruitful battlefield where it might make progress. Fighters went over to eastern Syria. A faction of the ISI group, led from 2010 by Iraqi academic Ibrahim al-Samarrai under the nom de guerre of Abu Bakr al-Baghdadi, gradually came into conflict with another ISI faction, and the two split in 2013. The other faction became the Nusra Front, an al-Qaeda affiliate loyal to 9/11 mastermind Ayman al-Zawahiri. The other ISI group, led by al-Baghdadi, became ISIL. ISIL took most of rural al-Raqqa province in eastern Syria, including the provincial capital of the same name, which it made its own capital. It also took the southeastern province of Deir al-Zor, and areas to the east and north of Aleppo.

With this territorial base, al-Baghdadi sent emissaries to Falluja, which acceded to ISIL in January 2014. Then its envoys convinced Sunni Iraqi politicians and resistance groups in Mosul, Beiji, Tikrit, Hit, and elsewhere to plot an uprising with them against what they saw as oppressive Shiite rule, which was staged in mid-June 2014. Soon thereafter, al-Baghdadi declared a "caliphate" or medieval Muslim polity combining religion and state. The ominous ISIL flag was adopted as a symbol around which ISIL officials hoped people would rally. They quoted Ottoman bureaucrat Ahmet Cevdet Pasha (d. 1895) to the effect that for a movement, a "flag is a sign of the coming together of their words and a proof of the unity of their hearts. They are like a single body and what knits them together is stronger than the bond of blood relatives" (McCants 2015: 345-46). This principle was adopted, then, from the modernizing Hamidian caliphate. The puritanical and harsh rule of ISIL, its reinstitution of slavery, and its taxation and fascination with gory spectacle fairly quickly induced buyer's remorse in urbane Sunni Arab populations, but with the police and army gone and local militias often destroyed by their former ISIL allies, they had few means of resistance.

In late summer and fall of 2014, the Obama administration decided that it had to intervene once again in Iraq, establishing a military command and eventually sending 4,500 or so US troops as trainers and advisers. The Iraqi special force's unit of the army was reinforced and emerged as an effective spearhead of the riposte to ISIL. The rest of the army, in disarray from corruption and the debacle at Mosul, proved much harder to retrain and deploy. Without a strong Iraqi army, Obama needed regional allies to push ISIL out of Sunni Arab cities. Ironically, the Obama administration depended heavily on pro-Iran Shiite militias in Iraq to roll back the caliphate in Iraq, along with the Peshmerga or Kurdistan national guard and some reconstituted brigades of the Iraqi army. Sometimes Iran, through the Iranian Revolutionary Guards Corps, also played a role. By 2016 some crack brigades of the Iraqi army had been trained and equipped, and real headway was made by Baghdad in retaking major cities. By spring 2017 the caliphate had largely been rolled up in Iraq as a territorial state. Whether 
the tyranny of the Shiite majority in Iraqi parliamentarism could recuperate its Sunni citizens remained, however, an open question.

\section{Conclusion}

The former Ottoman territories of the Middle East are heirs to two Ottoman solutions to the problem of religion-state relations. The most prevalent model is the subordination of the clergy and the religious institution to the state, and the reduction of clergy to civil servants where possible, in the tradition of Mehmet I. This model, now in place in Egypt and Tunisia, is characteristic of the Ottoman Empire in its glory years and would have been recognized by Suleyman the Magnificent. In some ways the separation was accelerated by the nineteenth-century Tanzimat reforms and their provincial equivalents, as in Mehmet Ali Pasha's Egypt.

The other major model inherited by the Middle East from the Ottomans was the latenineteenth- and early-twentieth-century Hamidian caliphate, where the head of state claimed both temporal authority and transnational religious authority as a means of combatting the colonial penetration of Muslim lands. The rise and fall of al-Baghdadi's caliphate in western and northern Iraq and in eastern Syria had much more proximate origins than the Ottoman legacy. Nevertheless, Usama Bin Laden's complaint about the calamities that had struck the disunited and supine Muslim community since 1924 suggests that part of the project here was the revival of the Hamidian caliphate. Like that Ottoman caliphate, ISIL rejected parliamentary democracy and the rule of law.

A Sunni caliphate, moreover, could not form the basis for rule of a pluralist society, with Shiites excluded in both cases, though the Hamidian state merely made them second-class citizens and targeted them for missionary work, while ISIL approached the problem with genocide on its mind. Neither the Ottoman nor colonial norms of governance, nor the nationalist states that succeeded them, developed methods for dealing with multiethnic states, or avoiding a tyranny of the majority.

Unlike the modernizing Ottoman caliphate, however, the caliphates of Mulla Omar and Ibrahim al-Samarra'i are characterized by a simplistic fundamentalism and a privileging of a literalist reading of aspects of the sharia, along with a ruthless disregard of the humane prohibitions in mainstream Islamic law and practice against murder or the killing of innocents. Of the two models, the likely victor (and the current victor if we count up territory held) is the state-centric subordination of religion. The latter-day caliphates have flourished only briefly, as radical and sectarian movements, in rugged territories where there was a vacuum of power.

\section{References}

Ahmed, Houriya, and Hannah Stuart (2010) "Hizb ut-Tahrir in the UK." Current Trends in Islamist Ideology 10: 143-209. 
Al-Damanhuri, Ahmad (1767-78) “al-Naf’ al ghazir fi salah al-Sultan wa al-wazir.” MS34, Egyptian National Library, Tymur Ijtima": 10.

Al-Rawi, A. K. (2014) "The Arab Spring and online protests in Iraq." International Journal of Communication 8 (1): 916-42.

Ali, Souad T. (2009) A Religion, Not a State: Ali 'Abd al-Raziq's Islamic Justification of Political Secularism. Salt Lake City: University of Utah Press.

Aljazeera (2015) "Watha' iqi yakshif dawr al-Maliki bi tasfiyat 'ulama' al-'Iraq." October 18, http://tinyurl. com/obnjda5.

Buzpinar, Tufan S. (1996) "Opposition to the Ottoman caliphate in the early years of Abdulhamid II: 1877-1882.” Die Welt des Islams 36 (1): 59-89.

Cole, Juan (1993) Colonialism and Revolution in the Middle East: Social and Cultural Origins of Egypt's 'Urabi Movement. Princeton, NJ: Princeton University Press.

(2002a) Sacred Space and Holy War: The Politics, Culture and History of Shi 'ite Islam. London: I. B. Tauris.

(2002b) "Shaikh al-Ra'is and Sultan Abdulhamid II: The Iranian dimension of Pan-Islam," in Israel Gershoni, Hakan Erdem, and Ursula Wokoeck (eds.) Histories of the Modern Middle East: New Directions. Boulder, CO: Lynne Rienner Publishers: 167-85.

— (2003) "The Taliban, women, and the Hegelian private sphere." Social Research 70 (3): 771808 .

(2009) Engaging the Muslim World. New York: Palgrave Macmillan.

(2011) "Shi' ite Parties and the Democratic process in Iraq," in Mary Ann Tetreault, Gwen Okruhlik, and Andrzej Kapiszewski (eds.) Political Change in the Arab Gulf States: Stuck in Transition. Boulder, CO: Lynne Rienner Publishers: 49-71.

(2014) The New Arabs: How the Millennial Generation Is Changing the Middle East. New York: Simon and Schuster.

Davison, Roderic (1963) Reform in the Ottoman Empire, 1856-1876. Princeton, NJ: Princeton University Press.

Dodge, Toby (2013) Iraq: From War to a New Authoritarianism. London: Routledge.

Fahmy, Khaled (1997) All the Pasha's Men: Mehmed Ali, His Army, and the Making of Modern Egypt. Cambridge: Cambridge University Press.

Fleischer, Cornell (1983) "Royal authority, dynastic cyclism and 'Ibn Khaldunism' in sixteenth-century Ottoman letters.” Journal of Asian and African Studies 18 (3-4): 198-220.

Karagiannis, Emmanuel (2006) "Political Islam in Uzbekistan: Hizb ut-Tahrir al-Islami." Europe-Asia Studies 58 (2): 261-80.

Kazimi, Nibras (2008) "The caliphate attempted." Current Trends in Islamist Ideology 7: 5-49.

Khan, Mirza Malkum (1970) in Ibrahim Safa'i (ed.) Asnad-i Naw-yaftih. Tehran: Chap-i Sharq: 119.

Liebl, Vernie (2009) “The caliphate.” Middle Eastern Studies 45 (3): 373-91.

Mansurnoor, Ilk Arifin (1992) "Religious scholars and state: Patterns of recruitment among the Ottoman "ulama.", Islamic Studies 31 (1): 35-51.

McCants, William (2015) The ISIS Apocalypse: The History, Strategy, and Doomsday Vision of the Islamic State. New York: St. Martin's Press.

Minault, Gail (1982) The Khilafat Movement: Religious Symbolism and Political Mobilization in India. New York: Columbia University Press.

Pankhurst, Reza (2010) "The caliphate, and the changing strategy of the public statements of al-Qaeda's leaders." Political Theology 11 (4): 530-52.

Pierret, Thomas (2013) Religion and State in Syria: The Sunni Ulama from Coup to Revolution. Cambridge: Cambridge University Press.

Sayyid-Marsot, Afaf Lutfi (1984) Egypt in the Reign of Muhammad Ali. Cambridge: Cambridge University Press.

Stuart, Villiers (1883) Egypt after the War. Vol. 1. London: John Murray.

Taymur, Ahmad (1967) A'lam al-Fikr al-Islami fi al-‘Asr al-Hadith. Cairo: Lajnat Nashr al-Mu'allafat al-Taymuriyyah. 
Teitelbaum, Joshua (2000) “Taking back' the caliphate: Sharīf Husayn Ibn 'Alī, Mustafa Kemal and the Ottoman caliphate.” Die Welt des Islams N.S. 40 (3): 412-24.

Terrill, W. Andrew (2014) "Understanding the strengths and vulnerabilities of ISIS." Parameters 44 (3): 13-23.

Wickham, Carrie (2013) The Muslim Brotherhood: Evolution of an Islamist Movement. Princeton, NJ: Princeton University Press.

Yazbak, Mahmoud (1997) "Nabulsi ulama in the late Ottoman period, 1864-1914.” International Journal of Middle East Studies 29 (1): 71-91.

Zeghal, Malika (1999) "Religion and politics in Egypt: The ulema of Al-Azhar, radical Islam, and the state (1952-94).” International Journal of Middle East Studies 31 (3): 371-99. 